\title{
MEDIA PEMBELAJARAN SEJARAH DI SMK NEGERI PONTIANAK
}

\author{
Astrini Eka Putri' ${ }^{1}$, Sariyatun², Nunuk Suryani ${ }^{3}$ \\ ${ }^{1}$ Mahasiswa Magister Pendidikan Sejarah Universitas Sebelas Maret Surakarta \\ 2Profesor Magister Pendidikan Sejarah Universitas Sebelas Maret Surakarta \\ 3Profesor Magister Pendidikan Sejarah Universitas Sebelas Maret Surakarta
}

1agashiastri13@gmail.com, 2sari_fkip_uns@yahoo.co.id, 3nunuk_suryani_uns@yahoo.com

\begin{abstract}
Research is expected could become the foundation of renewal in the use of media teaching history in state vocational schools in Pontianak. Based on it, then the researcher wants to describe about media learning customarily using by teachers in the process teaching history. Researcher interested to arrange research with a title "Media Teaching History in State Vocational Schools in Pontianak". Media uses teaching history in state vocational schools Pontianak has been good enough, since on average teachers using the existing facilities at the school in order to support learning activity. Learning activity history done by the teacher in this has been good enough, because it is already employing variations learning that are attractive. In the teaching process in two classes not only uses the media learning of a textbook, but had done some innovation that is by using media Microsoft Office PowerPoint.
\end{abstract}

Keywords: media learning, teaching history, vocational high school.

\begin{abstract}
ABSTRAK
Penelitian ini diharapkan dapat menjadi salah satu dasar dari pembaruan dalam penggunaan media pembelajaran sejarah di sekolah kejuruan negeri di Pontianak. Berdasarkan itu, maka peneliti ingin mendeskripsikan tentang media belajar digunakan oleh guru-guru dalam proses mengajar sejarah. Peneliti tertarik untuk melakukan penelitian dengan judul "Media Pembelajaran Sejarah di SMK Negeri Pontianak". Penggunaan media pembelajaran sejarah di SMK negeri Pontianak telah cukup baik, karena rata-rata guru telah menggunakan fasilitas yang ada di sekolah untuk mendukung kegiatan belajar. Aktifitas pembelajaran sejarah yang dilakukan oleh guru ini sudah cukup baik, karena menggunakan variasi pembelajaran yang menarik. Dalam proses mengajar dalam dua kelas tidak hanya menggunakan media belajar dari sebuah buku, tetapi telah melakukan beberapa inovasi yang ada dengan menggunakan media Microsoft Office PowerPoint.
\end{abstract}

Kata Kunci: media pembelajaran, pembelajaran sejarah, sekolah kejuruan.

\section{PENDAHULUAN}

Pendidikan adalah usaha untuk menyiapkan peserta didik melalui kegiatan pembimbingan, pengajaran, dan latihan bagi peranannya di masa yang akan datang, dalam pengembangan tugasnya guru dituntut untuk lebih kreatif dalam mendidik siswa dan melatih siswa dalam penguasaan konsep atau materi yang di sampaikan dapat dipahami oleh siswa.

Sejarah, dalam bahasa Indonesia dapat berarti riwayat kejadian masa lampau yang benar-benar terjadi atau riwayat asal usul keturunan. Umumnya sejarah dikenal sebagai informasi 
mengenai kejadian yang sudah lampau. Sebagai cabang ilmu pengetahuan, mempelajari sejarah berarti mempelajari dan menerjemahkan informasi dari catatan-catatan yang dibuat oleh perorangan, keluarga, dan komunitas. Pengetahuan akan sejarah melingkupi: pengetahuan akan kejadian-kejadian yang sudah lampau serta pengetahuan cara berpikir secara historis (Ahmadi, 2011:65)

Mata pelajaran sejarah merupakan salah satu pilar penting dalam dunia pendidikan di Indonesia maupun dunia. Dari sejarah, kita dapat mempelajari apa saja yang mempengaruhi kemajuan dan kejatuhan sebuah Negara atau sebuah peradaban. Selain itu, kita juga dapat mempelajari pengaruh perubahan politik, pengaruh dari filsafat sosial terhadap kehidupan manusia, serta sudut pandang budaya dan kemajuan teknologi sepanjang zaman.

Mata pelajaran sejarah merupakan salah satu pelajaran yang sangat penting dalam pengembangan potensi diri dan pengembangan karakter di sekolah. Karena itu pendidikan sejarah yang diajarkan di sekolah adalah pendidikan sejarah yang dapat menata nalar, membentuk kepribadian, mengembangkan sikap, menanamkan nilai-nilai, memecahkan masalah dan membekali siswa dengan keterampilan tertentu, selain itu, pelajaran sejarah dapat memfasilitasi perkembangan jiwa dan raga secara keseluruhan sehingga tercipta manusia Indonesia yang berkarakter kuat yang mampu mengangkat harkat bangsa. Hal ini sejalan dengan UU No. 20 tahun 2003 tentang sistem pendidikan nasional bahwa pendidikan adalah usaha sadar dan terencana untuk mewujudkan suasana belajar dan proses pembelajaran dengan demikian peserta didik secara aktif mengembangkan potensi dirinya untuk memiliki kekuatan spiritual keagamaan, pengendalian diri, kepribadian, kecerdasan, ahlak mulia serta keterampilan yang diperlukan dirinya, masyarakat, bangsa dan negara.

Seiring perkembangan zaman, pembelajaran sejarah memerlukan berbagai inovasi agar mudah dipahami oleh siswa serta meningkatkan minat belajar siswa terhadap sejarah. Hal penting untuk kemajuan kualitas pembelajaran sejarah, tidak hanya pada teori tetapi juga kepada hal-hal yang bersifat praksis. Oleh karena itu, diperlukan inovasi dalam pembelajaran sehingga lebih memberikan kesan bahwa pembelajaran yang menarik adalah proses pembelajaran yang menyenangkan namun tetap padat isi.

Jika di pandang dari tujuan mempelajari sejarah adalah untuk memberikan pengetahuan mengenai halhal penting dalam kehidupan manusia 
sepanjang sejarah yang nantinya dapat menjadi pandangan hidup kita dalam menghadapi masa depan. Tujuan tersebut dapat tercapai dengan baik jika siswa dapat mengerti dan memahami setiap materi sejarah yang disampaikan oleh guru.

Perkembangan dalam bidang teknologi haruslah dimanfaatkan oleh guru untuk membuat media-media pembelajaran yang menarik, agar peserta didik dapat memahami materi yang disampaikan. Penggunaan media visual seperti gambar dapat dimodifikasi dengan menambahkan dialog-dialog di dalamnya sehingga menjadi sebuah komik. Komik tidak hanya untuk media hiburan, tetapi komik juga dapat dimanfaatkan untuk media pembelajaran, seperti media pembelajaran Sejarah.

Kemajuan ilmu pengetahuan dan teknologi telah berpengaruh terhadap penggunaan alat-alat bantu mengajar di sekolah-sekolah dan lembaga pendidikan. Bagi sekolah yang sudah maju, telah menggunakan alat-alat tersebut sebagai alat bantu mengajar. Pembelajaran menjadi lebih efektif, efisien, dan menyenangkan. Kemajuan tersebut mendorong berbagai usaha perubahan, pendidikan di sekolahsekolah telah menunjukkan perkembangan pesat di segala bidang termasuk peralatan. Penggunaan peralatan, perlengkapan pendidikan, dan media pendidikan sudah mulai disesuaikan dengan kemajuan. Penggunaan alat-alat bantu mengajar, alat bantu peraga pendidikan, audio, visual, dan audio-visual disesuaikan dengan perkembangan saat ini (Sanaky, 2013:1-2). Perkembangan teknologi informasi telah mempengaruhi penggunaan berbagai jenis media, sebagai alat bantu dalam proses pembelajaran. Pembelajaran diharapkan dapat menggunakan alat-alat atau perlengkapan tersebut secara efektif dan efisien dalam pembelajaran di kelas.

Posisi media pembelajaran dalam kegiatan belajar mengajar merupakan proses komunikasi dan berlangsung dalam sistem. Media pembelajaran menempati posisi yang cukup penting sebagai salah satu komponen sistem pembelajaran. Tanpa media, komunikasi tidak akan terjadi dan proses pembelajaran sebagai proses komunikasi juga tidak akan bisa berlangsung secara optimal. Media pembelajaran adalah komponen integral dari sistem pembelajaran. Salah satu media yang unik dalam pembelajaran adalah media visual berupa komik digital (komik yang disajikan secara digital melalui media elektronik komputerisasi seperti nootebook, laptop, personal computer, tablet, dan smart phone). 
Perkembangan Ilmu Pengetahuan dan teknologi haruslah dimanfaatkan oleh guru untuk membantu proses pembelajaran dalam kelas. Guru haruslah inovatif dalam membuat media-media pembelajaran Sejarah. Media pembelajaran berperan sebagai alat yang mempunyai fungsi menyampaikan pesan pembelajaran. Dalam konteks ini, pembelajaran menunjuk pada sebuah proses komunikasi antara peserta didik dan sumber belajar (dalam hal ini komik pembelajaran). Komunikasi belajar akan berjalan dengan maksimal jika pesan pembelajaran disampaikan secara jelas, runtut, dan menarik.

Pada penelitian ini akan difokuskan pada media pembelajaran sejarah yang biasa digunakan di kelas X di dua SMK yakni SMK Negeri 3 Pontianak dan SMK Negeri 4 Pontianak. Fokus penelitian ini adalah sebagai media yang digunakan dalam pembelajaran sejarah di SMK Negeri Pontianak sekarang dan bentuk kebutuhan guru dan siswa terhadap media pembelajaran sejarah.

\section{METODE}

Metode penelitian yang digunakan adalah metode kualitatif. Penelitian dilakukan di SMK Negeri 3 Pontianak dan SMK Negeri 4 Pontianak. Adapun sumber data yang diperoleh berasal dari guru dan siswa serta sumber berupa dokumen seperti pada RPP (Rencana Pelaksanaan
Pembelajaran) yang digunakan guru untuk mengajar di kelas. Studi lapangan dilaksanakan untuk memperoleh informasi tentang persoalan-persoalan dalam pembelajaran di sekolah.

Penelitian dilakukan di SMK Negeri 3 Pontianak dan SMK Negeri 4 Pontianak. Subjek penelitian ini adalah siswa kelas $\mathrm{X}$ dan guru sejarah di SMK Negeri 3 Pontianak dan SMK Negeri 4 Pontianak.

Berdasarkan wawancara dengan guru dan siswa di SMK Negeri 3 Pontianak dan SMK Negeri 4 Pontianak akan diperoleh informasi mengenai: (1) media yang digunakan guru sehari-hari ketika mengajar mata pelajaran sejarah; (2) pengembangan media yang dilakukan guru ketika mengajar mata pelajaran sejarah; (3) proses pembelajaran sejarah; (4) hambatan yang dialami guru sejarah dalam proses pembelajaran sejarah berkaitan dengan media pembelajarannya.

Teknik pengumpulan data menggunakan teknik observasi langsung dan teknik komunikasi langsung (wawancara). Dengan alat pengumpul data berupa panduan observasi dan pedoman wawancara. Teknik analisis data menggunakan teknik analisis kualitiatif berupa triangulasi data, triangulasi sumber, dan triangulasi teori. 
HASIL DAN PEMBAHASAN

\section{Penggunaan Media Pembelajaran di SMK Negeri Pontianak}

Menurut Isjoni

Pembelajaran sejarah memiliki peran fundamental dalam kaitannya dengan guna atau tujuan dari belajar sejarah. Pembelajaran sejarah diharapkan dapat menumbuhkan wawasan peserta didik untuk belajar dan sadar akan guna dari sejarah bagi kehidupan sehari-hari sebagai individu maupun sebagai bangsa. Pembelajaran sejarah berkedudukan sangat strategis dalam pendidikan nasional sebagai 'soko guru' dalam pembangunan bangsa. Sejarah adalah ilmu tentang asal usul dan perkembangan peristiwa yang telah terjadi. Inti pembelajaran sejarah adalah bagaimana menanamkan nilai-nilai kepahlawanan, kecintaan terhadap bangsa, jati diri dan budi pekerti kepada anak didik. Pembelajaran sejarah menurut Djoko (2005: 4) merupakan suatu kegiatan mengembangkan kemampuan intelektual dan keterampilan untuk memahami proses perubahan dan keberlanjutan dan berfungsi sebagai sarana untuk menanamkan kesadaran akan adanya perubahan dalam kehidupan masyarakat melalui dimensi waktu.

Berdasarkan hasil pengamatan dan wawancara langsung yang telah dilakukan pada awal-awal penelitian sekitar pada bulan Februari 2015 di SMK Negeri 4 Pontianak dan SMK Negeri 3 Pontianak. Hasil observasi menunjukkan kegiatan pembelajaran sejarah di kedua sekolah tersebut sudah cukup baik, karena rata-rata guru sesudah menggunakan dengan baik fasilitas yang ada di sekolah guna menunjang kegiatan pembelajaran. Kegiatan pembelajaran sejarah yang dilakukan oleh guru selama ini sudah cukup baik, karena sudah menggunakan variasi pembelajaran yang cukup menarik.

Pembelajaran sejarah di SMK Negeri 4 Pontianak untuk kelas X diampu oleh Bapak Ivan. Berdasarkan penuturan Bapak Ivan, pembelajaran sejarah selama ini menggunakan buku paket yang mengacu pada kurikulum 2013 dengan disertai penggunaan media pembelajaran walaupun dengan tingkat intensitas tidak sering.

Penggunaan media pembelajaran sejarah selama di SMK Negeri 4 Pontianak, menurut penuturan Bapak Ivan mengatakan(3 November 2015) ;

Selama ini saya menggunakan media pembelajaran berbasis visual berupa media Microsoft office powerpoint untuk menyajikan materi sejarah di kelas... mengenai media pembelajaran yang mengacu pada sejarah lokal maupun kebudayaan lokal memang belum pernah saya lakukan, hal ini dikarenakan keterbatasan sumber dan waktu saya dalam merancang media pembelajaran tersebut. 
Hal ini juga diperkuat oleh pendapat Ibu Hervina selaku guru sejarah kelas X di SMK Negeri 3 Pontianak, menurut penuturan Ibu Hervina mengatakan (11 November 2015);

Pada proses pembelajaran sejarah saya termasuk sering menggunakan media pembelajaran. Namun, media pembelajaran yang saya gunakan terbatas hanya berupa media Microsoft office powerpoint dan terkadang saya juga menggunakan media audio visual berupa video pembelajaran mengenai peristiwa-peristiwa sejarah... namun, jika disinggung mengenai media pembelajaran yang mengacu pada kebudayaan lokal ataupun sejarah lokal memang belum pernah saya gunaka, dan hal ini dikarenakan keterbatasan sumber yang terkait materi sejarah lokal tersebut.

Selama observasi di SMK N 4 Pontianak dan SMK N 3 Pontianak Memang benar terlihat pada proses pembelajaran sejarah di SMK tersebut hanya menggunakan media Microsoft office powerpoint dan terkadang menggunakan media audio visual berupa video pembelajaran mengenai peristiwaperistiwa sejarah. Pembelajaran sejarah selama ini lebih mengejar waktu karena terbatasnya waktu pembelajaran sejarah terutama dalam hal penambahan media pembelajaran maupun sumber belajar pedamping selain buku paket.
Menurut Ibu Dita tentang materi sejarah daerah atau lokal selama ini tidak terlalu difokuskan dalam pembelajaran sejarah. Pengajaran sejarah selama ini di fokuskan pada materi yang ada dalam buku teks saja. Terkait media pembelajaran yang memuat sejarah lokal tersebut menurut Ibu Dita menjelaskan (5 November 2015);

Media pembelajaran yang biasa digunakan dalam proses pembelajaran sejarah hanya memuat materi yang sesuai dengan buku teks saja dan memang sangat jarang memasukkan unsure kebudayaan lokal maupun sejarah lokal didalamnya... untuk pengembangan khusus sejarah lokal tidak pernah saya buat, hanya saja dalam proses pembelajaran saya menjelaskan sedikit-sedikit dan itupun tidak sering.

Berdasarkan pernyataan ketiga guru sejarah diatas, bahwa selama ini guru kelas sudah menggunakan media pembelajaran yang menarik yaitu menggunakan media pembelajaran berupa media Microsoft office powerpoint . dan berdasarkan hasil observasi di sekolah tersebut untuk fasilitas yang ada cukup mendukung pembelajaran seperti adanya LCD, Globe, Peta, dan buku-buku. Namun, untuk media pembelajaran yang lebih variatif serta mengandung unsur sejarah lokal maupun kebudayaan lokal minim digunakan karena terbatasnya sumber serta waktu pembuatannya. 
Hasil wawancara dengan siswa juga memberikan gambaran tentang media pembelajaran yang digunakan guru selama ini. Saat disinggung perihal media pembelajaran yang mengandung unsur sejarah lokal hampir beberapa siswa yang dijadikan informan memberikan jawaban yang serupa bahwa media pembelajaran yang digunakan selama ini terlalu fokus pada daerah luar seperti daerah Jawa dan Sumatera. Materi yang dibahas pun dianggap siswa kurang memadai karena tidak menggambarkan karakteristik budaya lokal setempat.

Pada dasarnya yang diungkapkan siswa benar adanya bahwa seharusnya media pembelajaran yang digunakan dapat menggambarkan karakteristik budaya daerah lokal agar karakteristik dari budaya lokal tetap diajarkan pada siswa. Memasukkan budaya lokal dalam proses pembelajaran menjadi sangat penting agar nilai-nilai budaya yang ada tidak tergeser oleh budaya asing.

Sementara keberadaan media pembelajaran yang lebih variatif sangat dibutuhkan. Karena,media memiliki peran yang sangat penting dalam pembelajaran di sekolah. Media berfungsi sebagai penyampaian pesan, informasi atau materi yang diberikan oleh guru kepada peserta didik. Media dapat pula diartikan sebagai salah satu komponen komunikasi yang berfungsi untuk menyampaikan pesan dari komunikator menuju komunikan. (Criticios dalam Daryanto,2013:4)

Penggunaan media pembelajaran selama ini bagi siswa terlalu fokus pada sejarah di luar daerah saja, menurut Detri (siswi SMK N 4 Pontianak) mengungkapkan (3 November 2015);

Media pembelajaran yang digunakan guru selama ini berisi tentang sejarah nasional sangat jarang sekali membahas sejarah daerah. Padahal sejarah daerah lokal sangat penting untuk kami pelajari, agar kami mengetahui sejarah lokal serta kebudayaan lokal daerah kami.

Hal serupa pun peneliti dapatkan dari keterangan Carroline dan Iqra (Siswa SMK N 3 Pontianak) soal penggunaan media pembelajaran yang selama ini digunakan. Keduanya mengungkapkan hal yang sama yaitu hanya menggunakan media pembelajaran yang berfokus pada sejarah nasional bukan sejarah daerah lokal. Ibu Hervina juga selama ini sangat jarang membahas sejarah daerah lokal.

Menurut Bretz (dalam Anitah, 2009:123), menyatakan bahwa media adalah sesuatu yang terletak ditengahtengah, jadi suatu perantara yang menghubungkan semua pihak yang membutuhkan terjadinya suatu hubungan dan membedakan antara media komunikasi dengan alat bantu komunikasi. Perbedaannya adalah jika media komunikasi berkemampuan untuk 
menyajikan keseluruhan informasi dan menggerakkan saling tindak antara peserta didik dengan subjek yang dipelajari, sedangkan alat bantu komunikasi merupakan penunjang pada penyajian yang dilakukan oleh guru.

Berdasarkan teori para ahli dan kenyataan dilapangan menunjukkan media pembelajaran yang inovatif dan sesuai dengan perkembangan zaman sangat dibutuhkan disini. Selain berperan penting dalam penyampaian pesan materi dalam proses pembelajaran, media pembelajaran juga dapat mengefisienkan keterbatasan waktu maupun jarak untuk mencapai sumber belajar yang dibutuhkan. Karena, keberadaan media ini dapat mengemas sumber belajar itu dengan lebih ringkas dan mudah dijangkau oleh guru maupun siswa agar tercapai tujuan pembelajaran yang optimal.

Hasil observasi di atas baik dari guru dan siswa tentang media pembelajaran yang digunakan selama ini ada beberapa masalah antara lain ; (1) pembelajaran lebih fokus pada buku teks dan kurang ada pengembangan baik dari guru maupun siswa; (2) media pembelajaran yang digunakan masih minim pembahasan mengenai budaya lokal ataupun sejarah lokal.

Berdasarkan hasil wawancara dengan Bapak Ivan, mengenai kesadaran budaya pada siswa di SMK Negeri 4 Pontianak tidak terlalu buruk, beberapa siswa sudah mengetahui sejarah Kerajaan Pontianak serta kebudayaan yang mengiringinya walaupun hanya garis-garis besarnya saja. Beberapa siswa juga sudah pernah berkunjung ke Keraton Kadriah yang merupakan salah satu cagar budaya peninggalan Kerajaan Pontianak yang masih digunakan sebagai tempat tinggal keturunan Sultan Pontianak hingga sekarang. Hal ini juga seirama dengan penuturan Ibu Hervina , beliau menjelaskan bahwa memang beberapa siswa sudah mengetahui sedikit banyak mengenai Kerajaan Pontianak serta kebudayaan yang masih ada hingga sekarang.

Namun, hanya sekedar mengetahui saja ternyata belum cukup untuk membuat para siswa sadar akan kebudayaannya. Sosialisasi mengenai kebudayaan lokal serta sejarah lokal dalam pembelajaran di sekolah tentunya perlu dilakukan agar seluruh siswa dapat mengetahui kebudayaan lokal dan sejarah lokal daerahnya serta mampu meningkatkan kesadaran budaya untuk melestarikan kebudayaan lokal tersebut.

Berdasarkan hasil observasi yang dilakukan peneliti di SMK Negeri Pontianak, memang benar adanya bahwa hanya beberapa siswa saja yang mengetahui sejarah lokal dan 
kebudayaan lokal terutama mengenai sejarah Kerajaan Pontianak. Oleh karena itulah, peneliti merancang media pembelajaran yang sesuai agar siswa dengan mudah mendapatkan informasi terkait sejarah lokal dan dapat meningkatkan kesadaran budaya pada siswa untuk selalu melestarikan kebudayaan lokal yang ada lewat mempelajari sejarah lokal daerahnya.

\section{Kebutuhan Media Pembelajaran di SMK Negeri Pontianak}

Selama ini guru mata pelajaran sejarah di SMK N 4 Pontianak dan SMK N 3 Pontianak dalam kegiatan pembelajaran hanya menggunakan media Microsoft office powerpoint yang isi materinya hanya sesuai dengan buku teks saja. Guru mata pelajaran belum mampu mengembangkan sebuah media pembelajaran yang berisi unsur kebudayaan lokal dan sejarah lokal dikarenakan beberapa kendala yakni sumber dan waktu. Dalam hal ini sumber dan waktu merupakan kendala yang dihadapi guru, waktu yang tidak ada dan sumber yang terbatas mengenai sejarah lokal maupun kebudayaan lokal setempat, hal inilah yang menyebabkan guru mata pelajaran tidak dapat membuat media pembelajaran berupa media pembelajaran yang mengandung sejarah lokal dan kebudayaan lokal. Dari kegiatan pendahuluan ini diperoleh gambaran bahwa penggunaan media pembelajaran oleh guru yang mengandung unsur sejarah lokal dan kebudayaan lokal dapat dikatakan kurang. Namun, di sisi lain terdapat keinginan guru untuk mengembangkan media pembelajaran yang berbasis sejarah lokal dan kebudayaan lokal.

Berdasarkan temuan-temuan di atas dapat disimpulkan bahwa SMK Negeri Pontianak sudah cukup baik dalam melakukan proses pembelajaran dengan menggunakan media pembelajaran. Dalam proses pembelajaran juga sudah memanfaatkan fasilitas yang ada di sekolah. Guru dalam proses pembelajaran tidak hanya menggunakan buku teks tetapi juga sudah menggunakan media pembelajaran yang menarik berupa media berbentuk audio visual. Selain itu, siswa belum pernah diajak turun langsung untuk melihat peninggalan sejarah yang berada di sekitar lingkungan sekolah.

\section{PENUTUP}

Penggunaan media pembelajaran sejarah di SMK Negeri Pontianak sudah cukup baik, karena rata-rata guru seudah menggunakan dengan baik fasilitas yang ada di sekolah guna menunjang kegiatan pembelajaran. Kegiatan pembelajaran sejarah yang dilakukan oleh guru selama ini sudah cukup baik, karena sudah menggunakan variasi pembelajaran yang cukup menarik. Dalam proses 
pembelajaran di kelas guru tidak hanya menggunakan media pembelajaran berupa buku teks saja melainkan sudah melakukan sedikit inovasi yaitu dengan menggunakan media Microsoft office powerpoint yang ditayangkan menggunakan proyektor LCD. Namun, media pembelajaran yang digunakan sangat sedikit membahas mengenai sejarah lokal.

\section{REFERENSI}

Ahmadi, dkk. 2011. Metode Pembelajaran IPS Terpadu .Jakarta : Prestasi Pustakaraya.

Anitah, S. 2009. Teknologi Pembelajaran. Surakarta:Yuma Pustaka.

.2012. Media Pembelajaran. Surakarta : Yuma Pustaka.

Berkowitz, J. \& Packer, T. 2001. Heroes in the Classroom: Comic Books in Art Education. Journal National Art Education Association, volume 54, no. 6 , hal. 13

Daryanto. 2010. Media Pembelajaran. Yogyakarta: Gava Media 2013. Media Pembelajaran. Yogyakarta: Gava Media

Suryo, D. 2005. Paradigma sejarah di Indonesia dan kurikulum sejarah dalam makalah seminar nasional dan temu alumni PPS UNS. Sukarakata: PPS UNS

Emzir. 2012. Metodologi Penelitian Pendidikan: Kuantitatif \& Kualitatif. Jakarta: Rajawali Press.

Isjoni. 2007. Pembelajaran Sejarah dalam Satuan Pendidikan. Bandung: Alfabeta.
Sanaky, H. AH. 2013. Media Pembelajaran Interaktif-Inovatif. Yogyakarta: Kaukaba Dipantara.

\section{Wawancara}

Detri. Siswa Kelas XI SMK Negeri 4 Pontianak. (3 November 2015)

Hervina. Guru Sejarah SMK Negeri 3 Pontianak. (11 November 2015)

Ivan Bayu Putra. Guru Sejarah SMK Negeri 4 Pontianak. (3 November 2015)

Meydita Pratiwi. Guru Sejarah SMK Negeri 4 Pontianak. (5 November 2015) 